\title{
5
}

\section{Properties of Kinship Structure: Transformational Dynamics of Suckling, Adoption and Incest}

\author{
Fadwa El Guindi
}

\section{Introduction}

It is fitting in a volume edited by Warren Shapiro honouring the groundbreaking contribution by Harold Scheffler to the study of kinship semantics (Scheffler 1972; Scheffler and Lounsbury 1971 among other works) to present an analysis ${ }^{1}$ that integrates meaning and semantics of kinship terms, concepts and practices, in ways that reveal the logical properties of kinship structure, which is my primary concern.

\footnotetext{
1 This grew out of a systematic empirical study of kinship practices in Qatar carried out over a period of seven years (between 2006 and 2013). The primary data derive from systematic ethnographic observations made by the author on Qatari kinship practices and in-depth data obtained by a research team headed by the author on the subject of suckling kinship, including elicitation of Qatari kinship terms, over a period of three years. The research team consisted of colleague Wesam alOthman (former Associate Professor of Anthropology, Qatar University), and undergraduate students from the Department of Social Sciences majoring in Sociology and Anthropology, namely Sara alMahmoud, Alanoud al-Marri, Raneen Najjar, Dana al-Dossary and Fatima Abed Bahumaid. The field project was funded by two grants from the Qatar National Research Fund under its Undergraduate Research Experience Program: (a) UREP 06-012-5-003 (Milk Kinship: The Khalij Case) and (b) UREP 09-051-5-013 (Blood, Milk and Marriage: Kinship Behavior and Kinship Terminology in Qatar). The grant contents are solely the responsibility of the lead principal investigator and do not necessarily represent the official views of the Qatar National Research Fund. I especially thank colleague Wesam al-Othman for being a willing mentored and mentoring partner on the research project. Ego's case was elicited in parallel with the research team project.
} 
The ethnographic focus of this analysis is a phenomenon I call suckling, which relates to, but is separable from, the complex of practices commonly labelled 'milk kinship' (Altorki 1980; Conte 1987; Giladi 1998, 1999; Héritier-Augé and Copet-Rougier 1995; Héritier 1994; Khatib-Chahidi 1992; Lacoste-Dujardin 2000; Long 1996; Parkes 2004a, 2005). The latter is reported as historically common in the wider region covering the Balkans, the Mediterranean, and the Arab and the Islamic East (Parkes 2001, 2003, 2004b).

Suckling refers to a practice by which lactating women breastfeed babies who are not their own by birth, engendering new kin relations and networks, and generating new transformations that shift kin status among birth and marital kin (El Guindi 2011,2012a, 2012b, 2013; El Guindi and al-Othman 2013). Studying suckling, a practice that is quite prevalent in contemporary Arab society, particularly among kinship-intensive Arabian Arabs living in the regions of Arabia and the Arabian Gulf, led to new insights and perspectives on old issues, some of which are shared in this work. The thrust of analytic conceptualisation derives from primary data, but additional data were located in secondary sources such as existing studies and literature, religious documents, poetry and prose, as well as various visual sources.

I propose to establish two points: (1) that suckling, unlike other practices of breastfeeding, is kinship, thus belonging in kinship study not social relations; and (2) how integrating insights from the analysis of primary data about practices of suckling, adoption and incest in Qatar reveals general properties of kinship structure. The structure is described in this paper.

\section{What is suckling?}

It is interesting that the data collected show how suckling kin terms and categories are lexically marked relative to procreative kin terms and categories. Relatives among themselves and their familiars introduce relatives by suckling saying 'this is my mother, this is my sister', etc. Noticeably, the marker 'by suckling' is used in the presence of strangers to convey the exact nature of the relationship, but is dropped in ordinary, daily interactions among familiars. More can be said but this has to await analysis of the body of kin terminology data I gathered as part of 
the kinship project on Qatar, ${ }^{2}$ which cover Qatari Arabic kin terms of reference and address for kin by birth, marriage and suckling. I contend, however, from preliminary analysis that there is sufficient support for the modelling notion held by Scheffler, which considers nonprocreative kin to be 'as though' or 'modeled after' kin by birth (Scheffler 1970: 370). In this case, the reference is about suckling kin terms. ${ }^{3}$ Support for modelling is also found in Islamic Hadith (Prophetic Narratives, considered sacred but not divine) which quotes Muhammad (Islam's Prophet) as having stated that 'suckling prohibits what birth prohibits' (al-Tarmathi n.d.: 129-35; Sallama 2006). In the course of my fieldwork people often brought up this Hadith passage to emphasise suckling kinship's similarity in kinship character to birth kinship.

Equally compelling is the observation that the incest taboo applies equally to birth and suckling according to the Qur'an, the Hadith, and the ethnography. But, unlike the Qur'an, the Hadith, like the ethnography, recognises the attribute of lineal and lateral extensions beyond the suckling dyad. The notion of modelling in this case conveys analytic significance to the interrelationship among the three kinship practices recognised among the population of Qatar, and elsewhere as indicated. The analysis goes further by contending how aspects of the practice of women's suckling of nonbirth infants reveal a transformational character of kinship. This chapter builds on, but goes further than, descriptive and analytic accounts which I have recently published, based on primary field data and conclusions from various sources on local knowledge and cultural tradition, including original Islamic sources (El Guindi 2011, 2012a, 2012b, 2013, 2016; El Guindi and al-Othman 2013).

I have argued in earlier publications that sufficient analytic evidence supports the cultural view that the kind of suckling (Ar. rida'a) explored in the research project is considered kinship, alongside procreative (Ar. nasab $b^{4}$ ) and marital kinship (Ar. musahara). This claim of kinship status is not only culture-derived, but is also based on analytic criteria shared by kinship specialists. These criteria include classification in terminology (from

\footnotetext{
2 Most of it sits in a trunk shipped recently to my home in Los Angeles.

3 Arabic terms for marital kin are distinct from birth kin, and do not carry a marker such as 'in-law' as used in other terminological systems. The significance of the difference between the two kin-term sets, that of suckling and that of marriage, will be the subject for another work.

4 The Arabic term nasab is multivocal, sometimes used to refer to genealogical affiliation, other times to kin by marriage versus kin by birth. Formally, and as used in this account, it refers to procreative kin versus marital or suckling kin.
} 
preliminary analysis), observations of behavioural reciprocity, and the feature of lineality and laterality of recursions in marital prohibitions. It is observed that suckling extends links and prohibitions lineally and laterally beyond the original suckling dyad, and lifts avoidance and constructs new taboos that enable and disable marriage possibilities.

Here I seek to show that the structural property of transformationality is key to revealing a kinship structure integrating procreative, marital and suckling elements. The analysis draws upon field-derived ethnographic cases, which includes adoptive practices, an element in the process which made manifest the way prohibitions and avoidances are created and lifted. Adoption processes affirm suckling to be not only as an additional way whereby persons are incorporated as kin members, itself considered important, but also, if not more importantly, it becomes itself a process by which a transformational property of kinship structure is revealed. This leads to fresh insights into the construct of the incest taboo, and perhaps also into adoption.

Three decades before my field study on suckling in Qatar, Soraya Altorki published an article in 1980 entitled 'Milk-Kinship in Arab society: An Unexplored Problem in the Ethnography of Marriage', based on her field study of the practice of suckling in Saudi Arabia. This practice is also quite pervasive in other parts of the contemporary Arab world. But my decision to study suckling kinship independently grew out of an anthropological curiosity from directly observing and experiencing the intensity of such kinship activity in Qatari life. The constant encounter with lived kinship and especially the linguistic, ritual and interactional manifestations of suckling kinship (whether in classrooms or weddings) aroused my research interest and inspired my seeking two consecutive grants from the Qatar National Research Fund to systematically study suckling as it relates to kinship in general.

To capture the feel for the kinship-intensive environment among Arabs, I venture out of ethnography and into the memoir by Anthony Shadid, the late New York Times reporter who died covering the battlefield in Syria, in which he vividly describes, in what was to be his last book, his days in the hometown of his ancestors in Lebanon uncovering his roots as he participates in the project of remodelling his grandfather's house of stone. He covers ordinary daily life, familiar in any Arab society: 
As we sat there [the author writes], he kept introducing people to me, usually with a reference to their root in our family ... 'This man's grandmother is a Shadid' ... 'This man's mother is a Shadid' .. No conversations ... more common, more authoritatively deliberated ... more steeped in encyclopedic knowledge than those about genealogy... intermarriages ... that connected everyone to everyone else ... Tracking one's surname was a constant activity: Hikmat belonged to Bayt Farha, Isber to Bayt Samara ... names themselves were clues to the stories of origins' (Shadid 2012: 74).

As if in response to the view from afar, as it were, about kinship as mutuality of being (Sahlins 2013), Shadid goes on: 'Families always have conflict, he told me ... from the outside it looks okay' (2012: 109). It is not that the romanticised view of kinship, that 'people ... live each other's lives and die each other's deaths' (Sahlins 2013: 28), is wrong. It is incomplete. Some relatives behave kindly to each other, others do not. Perhaps this is what Marilyn Strathern means when she writes, 'Mutuality's largely benign connotations lead to some special pleading when it comes to malevolent or negative consequences' (1988: 392).

This analytical approach situates suckling in kinship as conventionally construed. It is thus indebted to Harold Scheffler's critique of kinship 'dismantlers' as he called them (Scheffler 2004: 294), and to Warren Shapiro, who has argued convincingly, using ethnographic evidence, against Janet Carsten's analysis of Malaysian ethnography (Shapiro 2011), an example of the so-called 'new kinship studies'. I shall show that radical claims of the new kinship studies do not adequately address the complexity of the phenomenon of kinship among Qataris.

To return to Altorki. She recognised suckling as a kinship practice, referring to it by the local Arabic term rida'a ('suckling'). Her article drew scholarly attention to the practice, otherwise neglected in anthropology, leading to further explorations. A century earlier than Altorki's study, William Robertson Smith briefly wrote on suckling in his classic publication on kinship and marriage in early Arabia (1885). Presumably he used information from the Qur'an, which is considered by Muslims to be the most sacred and divinely revealed source. There is significance to the fact that Qur'anic passages explicitly define kinship and recognise three forms: procreative, marital and suckling. This inclusive quality is further supported by other sources, including primary field-derived ethnography by Altorki on Saudi Arabia among others, and, independently, in my field-derived ethnography on Qatar. 
Peter Parkes (referenced earlier) was moved by Altorki's article to explore the phenomenon further. ${ }^{5} \mathrm{He}$ conducted a search of the literature and contributed a synthesis of historical materials describing the distribution of apparently similar practices, such as fosterage and wet-nursing, extending beyond Arab and Islamic regions, to include Christian groups in the Balkans. Some practices, he found, existed prior to Islam. Ethnographic accounts of social life in Hijaz during the first two centuries after Hijra (roughly the seventh and eighth centuries CE) suggest a pervasiveness of the practice of wet-nursing. The record, Parkes further found, points to a much earlier presence, as for example, in the Babylonian code of Hammurabi - the oldest comprehensive set of written laws, which gives a prominent position to 'Adoption and Wet-nursing' (Driver and Miles 1952: 383-406; Goody 1969).

Drawing on ethnographic insights, I contend that not differentiating among forms such as 'adoption', 'wet nursing', 'fosterage,' etc. results in confusion and ambiguity. Instead, I propose here that the 'milk phenomenon' subsumes a variety of traditions by which women breastfed infants who are not their own. The anthropological literature often refers to wet-nursing and suckling interchangeably. I maintain that such grouping may be a result of focusing on the substance of milk rather than on the properties of the kinship structure.

In his brief discussion on suckling kinship Smith brought out the link between the taboo against marriage and the practice of suckling. It could simply be a labelling problem when he chose to use the terms 'fostermother', 'foster-child', 'foster-brothers' but these are terminologically and semantically imprecise, since the Arabic original rida'a stands for nursing or suckling, not fostering. My preference is for the term suckling, to distinguish the phenomenon of my research focus from nursing one's own babies. It seems too that Smith's categorisation is ambiguous, particularly when he fluctuates among 'milk kinship', 'foster parenthood' and a combined 'milk-fosterage'. In Arabic there are two derivatives from the same linguistic root for nursing $r-d-'$ ' istirda' and rida'a, which refer to two identifiably different practices, wet-nursing and suckling.

5 At a reception at Kent University and before my own interest in the subject, Peter Parkes (see references) mentioned his interest in milk kinship, which a few years later turned into several publications. 
By converting the three kin positions specified by Smith into two dyadic relationships of mother-child and sibling-sibling, we can draw a parallel with the relations in the Qur'anic text as illustrated in Figure 16. The Qur'an expresses suckling relations in terms of dyads: 'suckling mothers', that is mother-child and 'sisters-in-suckling', that is sibling dyads. Smith wrote of 'foster-brothers' as well, but this is inaccurate: in the sura 4:23, sexually prohibited kin are positioned from a male reference point that, accordingly, refers to sisters and not brothers-that is, it assumes heterosexuality. Smith makes no reference to other sources like Shari'a, Jurisprudence, or extant ethnographic records.

\section{"I Brothered Them"}

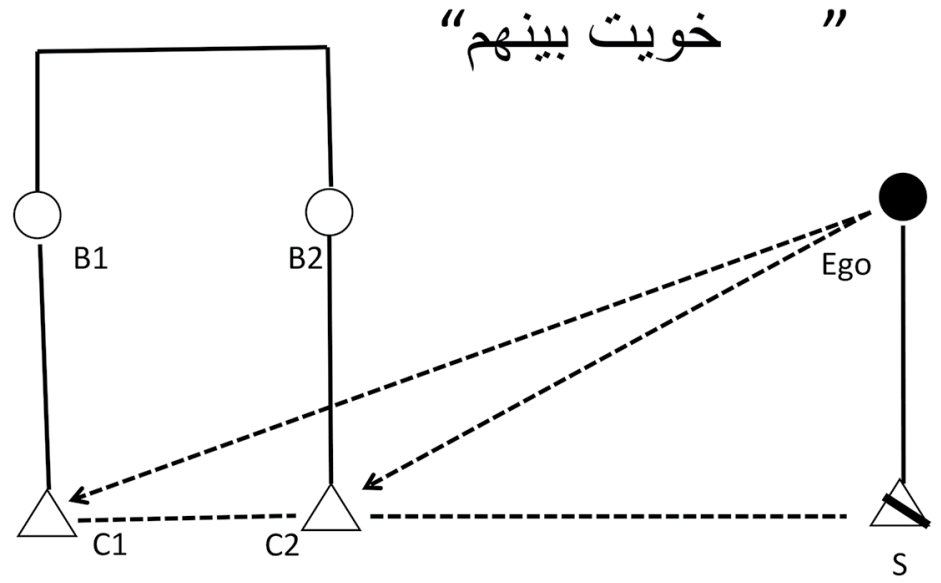

Suckling direction - arrow
Suckling link - broken line
Procreative link - solid line

Figure 12. Brothering matrilateral parallel cousins

Source: @ Fadwa El Guindi, 2014.

Arabs put much stress on mother's milk. When possible, nursing one's own infants is both desirable and preferred. However, since before Islam, women from wealthy families (as is the case with families of wealth elsewhere, including Europe) were not expected or obligated to nurse their own babies. Whether due to a mother's death, ill health, or wealth, urban Arabs frequently resorted to Badawi (Bedouin) women for nursing and early nurturing services, and this led to the development 
of an institution of wet-nursing or istirda' in the Arabian region. It was common and preferred at that time for families in urban centres such as Makka to utilise the service of Badawi women. Newborns were delivered to nonresident wet-nurses, to nurse for two years and be nurtured for several years beyond that. Wet-nursing was also carried out by resident slave women and household help, the latter continuing to this day in different parts of Arabia and the Gulf. Although, as already noted, this custom was practised prior to the advent of Islam, the Qur'an validated it as shown earlier by sacred text.

I distinguish wet-nursing as a paid service, whether in cash or kind, from the kind of suckling practices among women in the Arabian area and elsewhere in the larger Arabic-speaking region. Until empirical studies prove otherwise, I shall contend that most of these forms subsumed within the 'milk phenomenon' do not adequately qualify to be considered kinship.

Scholarly Arabic works suggest that suckling practices similar to those studied in my research project on Qatar existed in urban centres such as $\mathrm{Makka}^{6}$ at the beginning of Islam (for some references on these observations see al-Samhoudi 1505; Ibn Manthur 1311; Ibn Sa'd 844). It is also reported that suckling kinship varies in ethnographic details within the same region in Saudi Arabia as well as between the larger regions of Najd and Hijaz (Altorki 1980: 238).

\section{Groin, womb and nerve}

To convey the similarity of suckling to kin by birth, Smith wrote:

There is a real unity of flesh and blood between foster-mother and foster-child, or between foster-brothers; and so we find among the Arabs a feeling about milk-kinship so well established that Mohammed's law of forbidden degrees gives it all the effects of blood-relationship as a bar to marriage (1885: 176).

6 Reports of life in Yathrib, or Madina, to which Muslims immigrated escaping from Makka mention Jewish wet-nurses among the women suckling Arab infants during early Islam. See al-'Ayashi, Abdullah, bin Muhammad (1679); and Ibn Manthur, Mohammad bin Makram (1311). Lisan al-Arab is a comprehensive classical Arabic dictionary completed in $1290 \mathrm{CE}$, by the Arabic lexicographer Ibn Manthur (1233-1312 CE), al-Mațba a al-Kubra al-Amirīya, Bulaq 1883-1890 (20 volumes). 
His phrase 'Mohammed's law' indicates that he was referencing the Qur'an, probably through secondary information. His Biblical imagery'real unity of flesh and blood'-to describe suckling kinship relations is inaccurate, because it suggests identity with those of procreative kinship. The imagery of flesh and blood is used in very specific and limited circumstances among Arabs. Moreover, ethnography-based conceptualisations of Arabian kinship convey an alternative set of concepts: groin-womb-nerve.

Parentation is construed as both paternity in terms of 'groin' (solb) and maternity in terms of 'womb' (rahm). Thus among prohibited kin to a male are the wives of his 'sons by groin'. This phrase is employed in the text. 'Womb' is mentioned in the ethnographic interview in Figure 14 describing a relation forged by suckling as analogous to that by birth. More extended genealogical bonds are construed in terms of 'nerve' ('asab)—an observation widely supported by ethnography.

In an earlier publication I describe how the complementary duality of groin-womb represents how Arabs construe procreation (El Guindi 2012a), an idiom expressing the process of becoming 'birth kin'. By contrast, in the context of descent groups, genealogical relations are construed as generative with ascendants (see El Guindi 2012a for argument for ascent over descent) connected by 'asab (S1, 'nerve'). ${ }^{7}$ This is a point confirmed in numerous studies describing Badawi (or Bedouin) groups, notably in the ethnography by Ahmad Abu-Zeid (1991a: 213) on the Egyptian Sinai, where the local terms 'asib (S1, meaning 'nerve bound') and 'asiba (S1, 'nerve binding') are used to describe agnatic relations. He aptly describes (1991a, 1991b) Asab (S1, 'nerve') as the principle agnatically bonding Bedouin groups. Here, genealogy becomes the framework for corporateness and unity and the idiom by which relations are expressed, while, in reality, practices would be generatively fluid. Significantly, reputation and honour constitute the core elements for corporateness, which incorporated outsiders do not and cannot share or transmit (on this, see Lancaster 1997).

7 Syllable stress in the Arabic language is relevant to the meaning of the term. Henceforth stress will be marked in parentheses following the term by $\mathrm{S}$ for stress and a number designating the syllable $(1,2,3)$ to which the stress applies. 


\section{Crisscrossing paths of milk}

I was struck during fieldwork on suckling by a comment made by a Qatari woman, henceforth Ego, during an interview about her own suckling practices. ${ }^{8}$ Casually, Ego recounted: 'By suckling them, I brothered them.' She used the term khawithom, a gender-neutral Arabic verb form, meaning 'turned them into siblings'. After giving birth to a son of her own, Ego herself suckled two other male infants unrelated to her by birth or marriage, but related to each other as matrilateral parallel cousins. She went on to say: 'this way I also siblinged my son', meaning she gave brothers to her son by birth. These became her sons. This relationship is diagrammed in Figure 12.

One primary data-gathering technique I devised during the UREP kinship project was aimed at eliciting data on suckling. The research team was also seeking local knowledge among women who are the memory bearers of the paths of suckling, and who thus hold the key to decisions on permitted or prohibited spouses. The technique consists of templates designed on the basis of needed data about all possible suckling kin positions. Student researchers went to the field with these templates as a guide to elicit data on specific suckling kin positions, using unstructured openended interviews. In the case where the interviewee is not a participant or directly familiar with the kind of suckling represented in the template, the student interviewer was trained to construct a hypothetical case matching that of the template.

Both formulated techniques - the template and the hypothetical caseconstitute a methodological innovation meant to fulfil the need of eliciting particular kinship data. The specific template in Figure 13 was designed to elicit data by interviewing women (and occasionally men) about situations in which a male ego has a brother-in-suckling and a brother's son-in-suckling. This is demonstrated in Figure 13.

8 The extended interview was carried out over several months by myself and my colleague, Dr Wesam al-Othman, sometimes together and sometimes separately. This observation was made to me directly. 


\section{Field Kinship Elicitation}

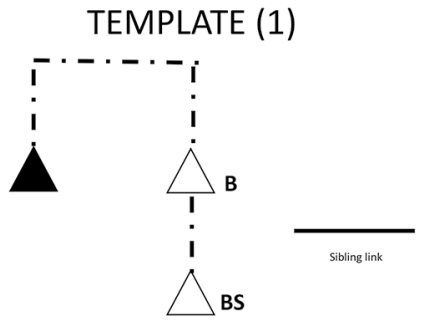

HYPOTHETICAL CASE (1)

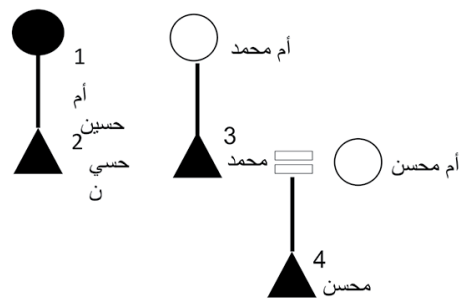

Figure 13. Template 1 and Hypothetical Case 1, employed in UREP project as a kinship elicitation method

Source: Designed by @ Fadwa El Guindi, 2014.

The interview itself, translated from Arabic by author, went as follows, with Raneen being the student interviewer and Ne'ma, a PalestinianJordanian living in Qatar, the interviewee. The interview is presented in Figure 14. To clarify, numbers next to names correspond to numbers in the diagram in Figure 13 assigned to kin positions:

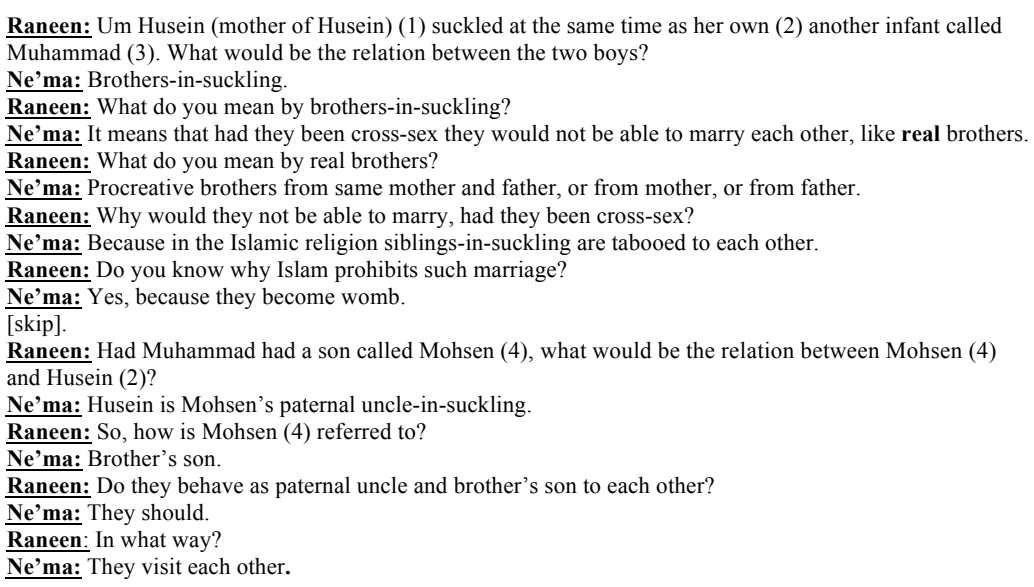

Figure 14. Ethnographic interview conducted by Raneen, student researcher on the project

Source: Translation and presentation by author. (C) Fadwa El Guindi, 2014.

A number of observations can be made from this interview:

a. Suckling is culturally considered kinship. 
b. Kinship is defined by the incest taboo.

c. Suckling terms are derivative from procreative terms and expected conduct is that expected between procreative kin.

d. Procreative siblings share mother and father, mother only, or father only.

e. Suckling relations go beyond the giving-receiving dyad, extending prohibitions horizontally and vertically.

\section{Tahrim: Prohibition and avoidance}

The Arabic word tahrim, with stress on the last syllable, signifies prohibition. I identify syllable stress for semantic reasons. In a kinship context tahrim means prohibition from marriage and derives from the root $h-r-m$ which 'is among the most important Arabic roots in the vocabulary of Islamic practice', according to some scholars (Reinhart 1995). Kevin Reinhart uses the terms 'forbidden' or 'taboo', evoking constraint and heightened sanctity (ibid.: 101). I have previously discussed the multivocal, interrelated derivatives of this root and their significance in Arab cultural conceptualisation (El Guindi 2003: 82-96). 'Haram means forbidden, prohibited, unlawful, taboo, sacred,' I wrote. 'It is a word widely used in the Arabic vocabulary ... [It] refers to all that is prohibited by divine authority' (ibid.: 84).

My monograph on privacy, first published in 1999, included analysis of Arabic-term concepts that are derivatives from the root $h-r-m$. Among these are: hurma (S1), harim (S2), ibram (S1), haram (S1), haram (S2), maharim (S2), mahram (S1), muharram (S2). There is also tahrim, the subject of this section. The key meaning, shared by these derivatives, is embedded in the notion of sacred sanctity, implying respect.

Tahrim denotes the quality of sacred sanctity, of forbidding or prohibiting. This denotation is confirmed by ethnographic data and ethnographic analysis of other records. The suckling field project shows that analysis of suckling must include tahrim as an interrelated process. As Figure 15 illustrates in graphics and text, two kin whose relationship is culturally established as characterised by the incest taboo would not be in an avoidance relationship. 


\section{How Incest Taboo \& Avoidance Work}

- Incest taboo prevents mother-son marriage (maharim)

- Incest taboo lifts mother-son avoidance

Space Can Be Shared

Behavioral \& Sartorial Avoidance Lifted

Incest Taboo $=$ Lifting Avoidance

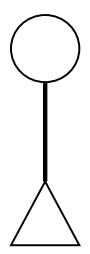

Avoidance $=$ Absence of Incest Prohibition

Figure 15. Depiction of mother-son and text illustrating incest and avoidance

Source: () Fadwa El Guindi, 2014.

Two Qur'anic verses (suras) deal with tahrim: sura 4:23 (al-Nisa') and sura 24:3 (al-Nur). The point of reference in the former is male, the latter female. Both are about kin prohibitions, but only sura al-Nisa' (4:23) includes references to suckling. The other $\operatorname{sura}(24: 3$, al-Nur) uses a female reference point that does not include suckling relations and is charted in an earlier publication (El Guindi 1999: 86). In Figure 16, I present an original graph of sura 4:23 (al-Nisa'), using standard notational symbols based on the text and maintaining the male reference point, in order to illustrate prohibited kin in relations of tahrim. ${ }^{9}$ Also included in Figure 16, at the top, is my original passage, which I have translated into English.

All prohibitions specified in sura 4:23 and illustrated in Figure 16 are reported to have been in effect in Arabia prior to Islam, except two: marrying two sisters (diagrammed in Figure 16) and a son's claim to his deceased father's wife. Sources indicate that both practices existed legitimately and pervasively in Arabia before new prohibitions became imposed in accordance with the relevant Qur'anic passages (Al-Magdoub 2003: 32).

9 I had employed conventional charting kin relations from Qur'anic texts previously, for the first time in 1999, primarily to clarify relations specified in Qur'anic passages in order to enhance analysis. It probably had the consequence of breaking any implicit taboo against such nonreligious use of the sacred text. 


\section{Qur'anic sura 4:23, al-Nisa' Prohibitions}

Prohibited to you are your mothers, daughters, sisters; father's sisters, mother's sisters; brother's daughters, sister's daughters; suckling mothers, sisters-insuckling; your wives' mothers; wives' daughters in your care, wives of your sons by groin, and combining two sisters in marriage [translation by author from the original Arabic; emphasis added].

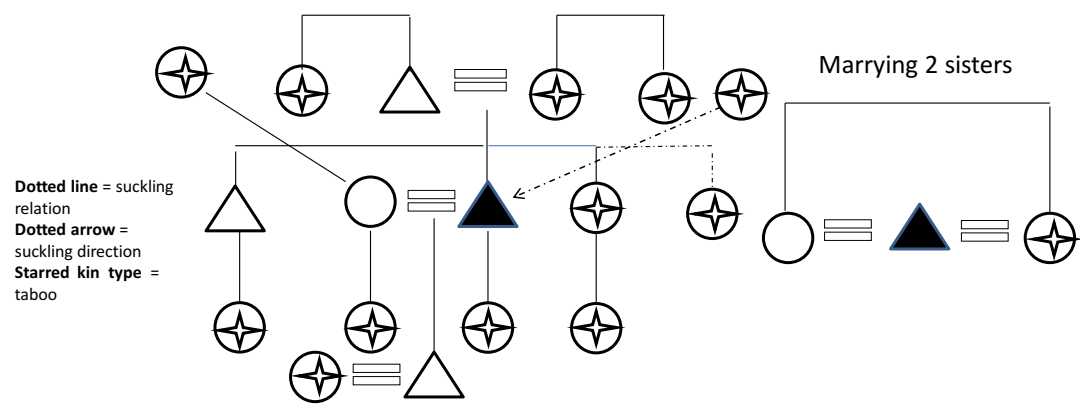

Figure 16. Depiction by author representing kin positions in the sura to demonstrate prohibitions

Source: () Fadwa El Guindi, 2014.

\section{The incest taboo and adoption revisited}

I find it remarkable that despite the universality of the incest taboo in human kinship, a significant anthropological discovery, two widely read volumes on kinship - the early compendium by Paul Bohannon and John Middleton (1968) and the more recent one by David Parkin and Linda Stone (2004) — do not include any chapters on incest. Perhaps this relates to the path taken in theorising the incest taboo, namely with focus on the hypotheses about its origin as contrasted with its occurrence in ongoing social life. Both have received attention in the history of our discipline (Cooper 1932; El Guindi and Read 2012; Fortune 1932; Freud 1831; Kuper 2002; Lévi-Strauss 1949; McCabe 1983; Turner and Maryanski 2005; Van Gelder 2013; Wilgaux 2000; Wolf 2014). Noticeably, discussion often blurs incest occurrence and incest taboo. The rule of prohibition is of great importance for understanding social organisational forms in anthropology. 
Dictionary and encyclopaedia definitions present incest as sexual intercourse between individuals related in certain prohibited degrees of kinship, and they note that every society has rules prohibiting incestuous unions. My concern here is with socially or legally recognised unions rather than statistical occurrences of sex among prohibited relatives. While sexual avoidance between primary kin is a near-universal in human society, cross-cultural studies show diversity in the content of the prohibited pool beyond parents and siblings.

In Islamic law maharim refers to a sexually prohibited pool. Muslims are minimally bound by the pool specified in the Qur'an. In a book dedicated to the topic of incest (Al-Magdoub 2003), referring to it as zina $^{10}$ al-maharim (adultery among prohibited kin), the term maharim is defined as 'females prohibited to males, by legislation, laws and customs, from having sexual relations whether in marriage or outside it' (ibid.: 87, my translation from Arabic). ${ }^{11}$ Al-maharim constitutes a set of kin (birth, marital and suckling) subject to marital prohibitions. By contrast, marriage between patrilateral parallel cousins, prohibited in some societies, is considered a desirable and preferred union and thus not subject to taboo.

Avoidances are manifested as formal behaviours, separation of spaces, and appearances in clothing and gestures that communicate distancing, such as the widely discussed practice of veiling by women. The Arabic for this kind of ritual avoidance is ihtijab, sharing the same root $h-j-b$ from which hijab ('Muslim woman's head-cover') derives (for a full discussion, see El Guindi 2003: 77-115).

Both revealing and puzzling in this connection is an incident reported in Hadith as having occurred in seventh-century Makka. I translate its recorded description this way: a Makkan woman called Zainab alUsdiyya came to the Prophet seeking guidance regarding the fact that her father died, leaving behind an owned slave who bore his son. He requested to see the son. Upon looking at him he declared him heir to the deceased, then asked Zainab to 'avoid' him (Ibn 'Abdul Birr 1070 (463 A.H.):321-323/4). By declaring him heir the boy was acknowledged as 'son of groin' of the deceased, but imposing avoidance by Zainab toward him means that he was not 'admitted' as her brother. Hence Zainab was

10 Zina is usually used to mean adultery, in this case adultery with prohibited women, while the term sifah is more appropriate for reference to incest.

11 For an extended analysis of the derivatives of $h-r-m$ see El Guindi (2003). 
instructed to ritualise space and appearance and to maintain distancing behaviours toward him. In other words, they were not recognised as siblings, and thus were not in a relationship of maharim to each other, in which case the incest taboo cannot apply and hence avoidance (ihtijab) is prescribed. Without access to independent additional details about this case, I would guess that the absence of marriage between genitor and slave, and the genetrix's status as slave, are the reasons behind the puzzling anomaly of being declared son with full inheritance rights but not brother to a 'daughter of groin'.

\section{Why adoption?}

The ethnography of Oceania has contributed in many ways to kinship debates (Berman 2014; Brady ed. 1976; Carroll 1970; Goodenough 1956; Malinowski 2001; Rivers 1914; Scheffler 1970; Schneider 1984; Silk 1980; Strathern 1988). Much of it centred on the pervasive phenomenon of the circulation of children in Oceania, referred to in scholarly works as 'adoption'. That most circulation was among procreative relatives generated much dispute on the relative importance of biology and culture. Other explanations have been social organisational (affiliation, succession, inheritance), transactional (as exchange), psychological (belonging and tension between givers and receivers), and sociobiological (predictability on sociobiological grounds of adoptive decisions). Jack Goody (1969) contributed a cross-cultural synthesis of the legal aspects of adoption and Vern Carroll edited a volume pulling together many ethnographic studies on this phenomenon (Carroll 1970).

In his introduction to that volume Carroll defined adoption as 'any customary and optional procedure for taking as one's own a child of other parents' (Carroll 1970: 3). In the United States, 'adoption' involves securing a child of unknown parentage from an 'adoption agency', and resorting to complicated legal proceedings (Carroll 1970: 4). Carroll goes on to write that American adoption is often a transaction involving total strangers, whereas adoption in Oceania is generally a transaction between close relatives (Carroll 1970: 7).

But data systematically gathered in the field, as well as secondary data from Arab ethnography, can shed a different light on the notion of adoption. Adoption occurs among Arabs, but it is not recognised as kinship. It is not socially admissible as a means to incorporate nonkin into an existing 
kinship network. Nonetheless, the sociological question emerging from my data is: Can adoption somehow bring about a transformation from stranger to kin?

Let me return to Ego, the woman who 'brothered' two infants. Her son by birth had died shortly after birth from some ailment and, after deliberation with her husband, she began the process of adoption, since her advanced age would prevent another pregnancy. Adoption is problematic-Islam does not legalise it and, as noted, society does not recognise it as a means to incorporate new kin. Relating how adoption in Ego's case was calculated conveys processes central to the analysis of kinship structure.

After a long delay Ego succeeded in, officially but not legally, adopting a male baby. By then her lactation had stopped. Why is lactation important in this case? Ego and her husband are not genetrix and genitor (procreative mother and father) to the baby, and since adoption is not recognised as creating kinship, the boy remains a 'stranger' even after he is adopted. Hence the incest taboo cannot apply, and since he is male, avoidance is required from resident females. The incest taboo would then be the only means for the adoptee to become a kinsman. The activation of the incest taboo lifts prescribed, ritualised avoidance among strangers. The other means to lift avoidance is marriage, irrelevant to this case. In order to become mother to her adopted son a woman has to nurse him, which was no longer a possibility for Ego since her lactation phase had ended.

Since suckling is not confined to procreative mothers and since any lactating woman qualifies to suckle within accepted social and cultural norms, Ego's calculation involved locating an appropriate lactating woman at the time the baby boy was adopted. What she did was to time adoption with the expected birth by her brother's wife. So once adoption actually took place the brother's wife was lactating, and was asked to nurse the adoptee along with her own child. Given the cultural rule discussed earlier, adoptee and birth son who cosuckle become siblings. This way the suckling brother's wife became the adoptee's mother, and by extension Ego's brother became father, and by further extension, Ego became paternal aunt to the adopted boy. And the cosuckled infants became siblings.

Given the cultural importance of enforcing cross-sex avoidance in cases of nonincestuous relations, Ego continued to have doubts about the sufficiency of suckling by her brother's wife for lifting the otherwise prescribed avoidance. Becoming paternal aunt might be adequate, but 
there was uncertainty as to its sufficiency. Ego wanted to 'mother' the adoptee, as if she were his birth mother; that is, to nurture him without the constrictions of avoidance. The solution was to resort to a means which would 'double lock' incest, as it were.

The granddaughter of Ego's husband from a previous marriage (who lived in another country) was lactating and she was asked to nurse the adoptee. By doing so, Ego's husband (grandfather of the suckling woman) became grandfather to the adoptee (who is now sibling to his birth great-grandson) and, by extension, Ego became the adoptee's grandmother. Ego is now both paternal aunt via suckling through the procreative chain of kin, and grandmother through the affinal chain of kin. This doubly-secured lifting of avoidance enabled Ego to proceed with 'mothering' the adoptee.

However, even though Ego was able to become the adoptee's procreative kin through both birth and marital channels, the ethnographic case shows that without direct suckling of the adoptee she could never become his mother. The only means for transforming stranger to kin are marriage, where applicable, or suckling, when possible. Suckling, carefully calculated, re-categorises procreative kin and lifts avoidance when it activates the incest taboo. It can construct and reconstruct kin by birth or kin by marriage. It can convert maternal kin into paternal kin and vice versa. The details of the ethnographic case presented here reveal structures and transformations with implications for kinship by birth, by marriage and by suckling. Finally, it invites reconsiderations of both anthropological notions of adoption and the incest taboo.

\section{General conclusions}

In conclusion, I restate what my analysis in this chapter sought to convey. First, I distinguished suckling as studied in Qatar and practices in contiguous areas from other practices of the 'milk phenomenon' in the region and those reported as having existed historically. Analysis of the practice reveals properties necessary as criteria of kinship among Qataris.

Second, analysis of ethnographic data on suckling showed interrelatedness among procreative, marital, and suckling kinship practices, which therefore constitute an integrated structure of kinship for Qataris. Third, and finally, I conclude that studying kinship and the process of 'kinshipping', as it were, using in-depth primary data, can tell us 
something about what kinship 'is all about': namely a dynamic system of relations and transformations, a structure and a social reality in human life considerably more complex than reductionist claims can reveal. Suckling has a transformative function in kinship relations, constructs new links, creates new relations, transforms existing ones, intensifies and interlocks kin relations, prohibits some relations and creates others. It categorises and re-categorises kinship by birth and kinship by marriage. Adoption in Qatar poses a challenge to the cultural system, which legally disqualifies it but allows it to occur.

\section{References}

Abu-Zeid, Ahmad. 1991a. al-Mujtama'at al-sahrawiyya f-Misr: shamal sina', dirasa etnographiyya lil-nuthum wal-ansaq al-ijtima'iyya (Desert Communities in Egypt, North Sinai - Ethnographic Study of Social Structure and Organization). Cairo: al-Markaz al-Qawmi lil-Buhuth al-Ijtima’iyya wal-Jina’iyya, Qism Buhuth al-Mujtama' at al-Rifiyya wal Sahrawiya (National Centre for Social and Criminological Research Research on Rural and Desert Communities Section).

- - 1991b. al-Mujtamaat al-sahrawiyya i Misr. shamal sina, dirasa etnographiyya lil-nuthum wal-ansaq al-ijtimaiyya (Desert Communities in Egypt, North Sinai - Ethnographic Study of Social Structure and Organization). Cairo: al-Markaz al-Qawmi lil-Buhuth al-Ijtimaiyya wal-Jinaiyya, Qism Buhuth al-Mujtamaat al- al-Rifiyya wal Sahrawiya (National Centre for Social and Criminological Research - Research on Rural and Desert Communities Section).

al-'Ayashi, Abdullah, bin Muhammad. 1679. al-Madina al-munawwara fi riblat al-'ayashi; reprint 1988, edited by Muhammad Amahzun. Kuwait: Dar al-Arqam (page references are to the reprint edition).

Al-Magdoub, Ahmad. 2003. Zina al-maharim: al-shaytan fi buyutna (Incest: The Devil in our Households) (Arabic). Cairo: Maktabat Madbouli.

al-Samhoudi, Ali Bin Abdullah. 1972 [1505]. Khulasat al-wafa' bi-akhbar dar al-mustafa. al-Madina al-Munawwara. Saudi Arabia: al-Maktaba al-'Ilmiyya. 
al-Tarmathi. n.d. Sunan al-tarmathii: The Book on Suckling (Arabic), Book 12. Dar Al-Gam'a al-Gadida.

Altorki, Soraya. 1980. 'Milk-kinship in Arab society: An unexplored problem in the ethnography of marriage'. Ethnology 19(2): 233-44. doi.org/10.2307/3773273

Berman, Elise. 2014. 'Holding on: Adoption, kinship tensions, and pregnancy in the Marshall Islands'. American Anthopologist 116(3): 578-90. doi.org/10.1111/aman.12116

Bohannon, Paul and John Middleton (eds). 1968. Kinship and Social Organization. Garden City, NY: American Museum Sourcebooks in Anthropology, the Natural History Press.

Bonte, Pierre (ed.). 1994. Epouser au plus proche: Inceste, prohibitions et strategies matrimoniales autour de la Méditerranée. Paris: Editions de l'Ecole des Hautes Etudes en Science Sociales.

Brady, Ivan (ed.). 1976. Transactions in Kinship: Adoption and Fosterage in Oceania. Association for Social Anthropology in Oceania Monograph 4. Honolulu: University of Hawaii Press.

Carroll, Vern. 1970. 'Introduction: What does "adoption" mean?' In Adoption in Eastern Oceania, edited by Carroll, 3-17. Honolulu: University of Hawaii Press.

Carroll, Vern (ed.). 1970. Adoption in Eastern Oceania. Association for Social Anthropology in Oceania Monograph 1. Honolulu: University of Hawaii Press.

Carsten, Janet. 1997. The Heat of the Hearth: The Process of Kinship in a Malay Fishing Community. Oxford: Clarendon Press.

- 2000. Cultures of Relatedness: New Approaches to the Study of Kinship. Cambridge: Cambridge University Press.

Code of Hammurabi of Babylon. ca. 2250 B.C.; reprint 1952, as The Babylonian Laws, Oxford: Clarendon Press, 1952, edited by G.R. Driver and John C. Miles (page references are to the reprint edition).

Conte, Eduoard. 1987. 'Alliance et parenté élective en Arabie ancienne. Éléments d'une problématique'. L'Homme 27(102): 119-38. doi.org/ 10.3406/hom.1987.368814 
Cooper, John M. 1932. 'Incest prohibitions in primitive culture'. Primitive Man 5(1): 1-20. doi.org/10.2307/3316422

Driver, G.R., and J.C. Miles. 1952. The Babylonian Laws, vol. 1. Oxford: Clarendon Press.

El Guindi, Fadwa. 1999. Veil: Modesty, Privacy and Resistance. Oxford and New York: Berg.

—_. 2011. 'Kinship by suckling: Extending limits on alliance in endogymous systems'. In Anthropologicheskii Forum (Forum for Anthropology and Culture), Peter the Great Museum of Anthropology and Ethnography ((Kunstkamera), Russian Academy of Sciences, Special Forum on Kinship 15(7): 381-84.

__. 2012a. 'Milk and blood: Kinship among Muslim Arabs in Qatar'. Anthropos 107(2): 545-55.

—_. 2012b. 'Suckling as kinship'. Anthropology Newsletter 53(1): n.p.

__ 2013. 'Inceste, adoption et allaitement: logiques et dynamiques de l'évitement'. Incidence Revue 19: 121-37.

—_. 2016. 'Beyond fitness and nurture: The kinship paradox'. Structure and Dynamics: eJournal of Anthropological and Related Sciences 9(2): 66-78.

El Guindi, Fadwa and Wesam al-Othman. 2013. 'Transformationality and dynamicality of kinship structure'. Structure and Dynamics: eJournal of Anthropological and Related Sciences 6(1). Online: escholarship.org/ucl item/98z0r296 (accessed 6 June 2017).

El Guindi, Fadwa and Dwight Read. 2012. 'Westermarck hypothesis reconsidered: A comment on Kushnick and Fessler'. Current Anthropology 53(1): 134-35. doi.org/10.1086/663576

Fortune, R. 1932. Encyclopedia of the Social Sciences, vol. VII, s.v. Incest. New York: Macmillan.

Freud, Sigmund. 1831. Totem and Taboo. New York: The New Republic Edition. 
Giladi, Avner. 1998. 'Breast-feeding in medieval Islamic thought: A preliminary study of legal and medical writings'. Journal of Family History 23(2): 107-23. doi.org/10.1177/036319909802300201

-1999. Infants, Parents and Wet Nurses: Medieval Islamic Views on Breastfeeding and their Social Implications. Leiden: Brill.

Goodenough, Ward H. 1956. 'Componential analysis and the study or meaning'. Language 32(1): 195-216. doi.org/10.2307/410665

Goody, Jack R. 1969. 'Adoption in cross-cultural perspective.' Comparative Studies in Society and History 11(1): 55-78. doi.org/10.1017/ S0010417500005156

Héritier, Françoise. 1994. 'Identité de substance et parenté de lait dans le monde arabe'. In Epouser au plus proche: Inceste, prohibitions et strategies matrimoniales autour de la Méditerranée, edited by Pierre Bonte, 149-64. Paris: Editions de l'Ecole des Hautes Etudes en Science Sociales.

Héritier-Augé, Françoise and Elizabeth Copet-Rougier. 1995. La Parenté Spirituelle. Paris: Éditions des archives contemporaines.

Ibn 'Abdul Birr, Yusuf bin Abdullah. 1070. al-Isti'ab fi asma' al-ashab, bihamish kitab al-isaba libn hagar. Dar el-Fikr.

Ibn Manthur, Mohammad bin Makram. 1311. Lisan al-Arab al-muhit. Beirut, Lebanon: Dar Lisan al-Arab.

Ibn Sad, Muhammad. 844. al-Tabaqat al-kubra; reprint 1985, Beirut: Dar Sadir (page references are to the reprint edition).

Jones, Doug and Bojka Milicic (eds). 2011. Kinship, Language, and Prehistory: Per Hage and the Renaissance in Kinship Studies. Salt Lake City: University of Utah Press.

Khatib-Chahidi, Jane. 1992. 'Milk-kinship in Shi'ite Islamic Iran'. In The Anthropology of Breast-feeding: Natural Law or Social Construct, edited by Vanessa Maher, 109-32. Oxford: Berg.

Kuper, Adam. 2002. 'Incest, cousin marriage and the origin of human sciences in nineteenth century England'. Past and Present 174(1): 158-83. doi.org/10.1093/past/174.1.158 
Lacoste-Dujardin, Camille. 2000. 'La filiation par le lait au Maghreb'. L'Autre. Cliniques, Cultures et Societe 1: 69-76. doi.org/10.3917/lautr. 001.0069

Lancaster, William. 1997. The Rwala Bedouin Today. 2nd edition. Prospect Heights, Illinois: Waveland Press.

Lévi-Strauss, Claude. 1949. Les structures élémentaires de la parenté. Paris: Presses Universitaires Françaises; rev. and trans. James Harle Bell and John Richard von Sturmer, edited by Rodney Needham as The Elementary Structures of Kinship. Boston: Beacon Press, 1969 (page citations are to the translated edition).

Long, Debbi. 1996. 'Milky ways. Milk kinship in anthropological literature and in a Turkish village community'. MA thesis, University of Nijmegen.

Malinowski, Bronisław. 1927. Sex and Repression in Savage Society. Kegan Paul, Trench, Trubner and Co. Ltd; reprint 2001, Chicago: University of Chicago Press (page references are to the reprint edition).

McCabe, Justine. 1983. 'FBD marriage: Further support for the Westermarck hypothesis of the incest taboo?' American Anthopologist 85(1): 50-69. doi.org/10.1525/aa.1983.85.1.02a00030

Parkes, Peter. 2001. 'Alternative social structures and foster relations in the Hindu Kush: Milk kinship allegiance in former mountain kingdoms of northern Pakistan'. Comparative Studies in Society and History 43(1): 4-36. doi.org/10.1017/S0010417501003565

- _ 2003. 'Fostering fealty: A comparative analysis of tributary allegiances of adoptive kinship'. Comparative Studies in Society and History 45(4): 741-82. doi.org/10.1017/S0010417503000343

—_. 2004a. 'Fosterage, kinship, and legend: When milk was thicker than blood?' Comparative Studies in Society and History 46(3): 587-615. doi.org/10.1017/S0010417504000271

—_. 2004b. 'Milk kinship in Southeast Europe: Alternative social structures and foster relations in the Caucasus and the Balkans'. Social Anthropology 12(3): 341-58. doi.org/10.1111/j.1469-8676. 2004.tb00112.x 
—. 2005. 'Milk kinship in Islam: Substance, structure, history'. Social Anthropology 13(3): 307-29. doi.org/10.1111/j.1469-8676. 2005.tb00015.x

Parkin, David and Linda Stone. 2004. Kinship and Family: An Anthropological Reader. Oxford: Blackwell Publishers.

Reinhart, A. Kevin. 1995. 'Harām'. In The Oxford Encyclopedia of the Modern Islamic World, 4 vols, edited by John L. Esposito, vol. 2, 101. New York: Oxford University Press.

Rivers, William H.R. 1914. The History of Melanesian Society, 2 vols. Cambridge: Cambridge University Press.

Sahlins, Marshall. 2013. What Kinship Is - And Is Not. Chicago: University of Chicago Press. doi.org/10.7208/chicago/9780226925134.001.0001

Sallama, Amer Hussein. 2006. al-Muharramat min-al-nisa' bi-sabab alMusahara. Alexandria: Dar al-Iman lil Tab’ wal Nashr wal Tawzi'.

Scheffler, Harold W. 1970. 'Kinship and adoption in the northern New Hebrides'. In Adoption in Eastern Oceania, edited by Vern Carroll, 369-89. Association for Social Anthropologists in Oceania Monograph 1. Honolulu: University of Hawaii Press.

- 1972. 'Kinship semantics'. Annual Reviews in Anthropology 1: 309-28. doi.org/10.1146/annurev.an.01.100172.005121

- 2004. 'Sexism and naturalism in the study of kinship'. In Kinship and Family: An Anthropological Reader, edited by Robert Parkin and Linda Stone, 294-308. Malden, MA: Blackwell.

Scheffler, Harold W. and Floyd G. Lounsbury. 1971. A Study in Structural Semantics: The Siriono Kinship System. Englewood Cliffs, NJ: Prentice Hall.

Schneider, David M. 1984. A Critique of the Study of Kinship. Ann Arbor: University of Michigan Press. doi.org/10.3998/mpub.7203

Shadid, Anthony. 2012. House of Stone: A Memoir of Home, Family, and a Lost Middle East. Boston: Houghton Mifflin Harcourt. 
Shapiro, Warren. 2011. 'What is Malay kinship primarily about? Or the new kinship studies and the fabrication of an ethnographic fantasy'. In Kinship, Language, and Prehistory: Per Hage and the Renaissance in Kinship Studies, edited by Doug Jones and Bojka Milicic, 141-51. Salt Lake City: University of Utah Press.

Silk, Joan B. 1980. 'Adoption and kinship in Oceania'. American Anthropologist 82(4): 799-820. doi.org/10.1525/aa.1980.82.4.02a 00050

Smith, William Robertson. 1885. Kinship and Marriage in Early Arabia. Cambridge: Cambridge University Press.

Strathern, Marilyn. 1988. The Gender of the Gift: Problems with Women and Problems with Society in Melanesia. Anthropology Series. Berkeley: University of California Press. doi.org/10.1525/ california/9780520064232.001.0001

Turner, Jonathan and Alexandra Maryanski. 2005. Incest: Origins of the Taboo. Boulder, CO: Paradigm Publishers.

Van Gelder, Geert Jan. 2013. 'Incest and inbreeding'. In Encyclopedia Iranica, vol XIII, 5-6.

Wilgaux, Jérôme. 2000. 'Entre inceste et échange: Réflexions sur le modèle matrimonial athénien'. L'Homme 154-55: 659-76. doi.org/10.4000/ lhomme. 54

Wolf, Arthur P. 2014. Incest Avoidance and the Incest Taboos: Two Aspects of Human Nature. Stanford, CA: Stanford University Press. 
This text is taken from Focality and Extension in Kinship: Essays in Memory of Harold W. Scheffler, edited by Warren Shapiro, published 2018 by ANU Press, The Australian National University, Canberra, Australia.

doi.org/10.22459/FEK.04.2018.05 